\title{
SERIES OF AGRICULTURE IN THE STATISTICAL OFFICE OF THE REPUBLIC OF SERBIA DATABASE ${ }^{1}$
}

\author{
Jelena Radović - Stojanović2, Aleksandra Zečević ${ }^{3}$ Zorica Kojčin ${ }^{4}$
}

\section{Summary}

The objectives of this Paper have been to examine which data on agriculture can be found in the Statistical Office of the Republic of Serbia Database, and what are the possibilities for the use of the Database in the research and analysis of agriculture. The Statistical Office of the Republic of Serbia Database physically represents normalized database formed in DBMS SQL Server. The methodological approach to the Paper subject is primarily related to modelling and the way of using Database. The options of accession, filtering and downloading of data from the Database are explained. The technical characteristics of the Database were described, indicators of agriculture listed and the possibilities of using Database were analysed. We examined whether these possibilities could be improved. It was concluded that improvements were possible, first, by enriching Database with data that are now only available in printed publications of the Office, and then, through methodological and technical improvements by redesigning the Database modelled on cloud founded databases. Also, the application of the achievements of the new multidisciplinary scientific field - Visual Analytics would improve visualization, interactive data analysis and data management.

Key words: database, agriculture indicators, structure series, time series, Serbia JEL: $Q 10, C 81$

1 Paper is a part of research within the project no. III 41030 - Biological mechanisms, nutritional intake and status of polyunsatured fatty acids and folate: Improving nutrition in Serbia, financed by the Ministry of Education, Science and Technological Development of the Republic of Serbia. Project period: 2011-2015.

2 Jelena V. Radović - Stojanović, Ph.D., Assistant Professor, Academy of Criminalistic and Police Studies, Cara Dušana Street no. 196, 11080 Belgrade, Serbia, Phone: +381 64892 26 52, E-mail: jelena.rs@kpa.edu.rs

3 Aleksandra T. Zečević, Ph.D., Assistant Professor, University of Belgrade, Faculty of Economics, Kamenička Street no. 6, 11000 Belgrade, Serbia, Phone: +381 6944966 21, E-mail: azecevic@ekof.bg.ac.rs

4 Zorica D. Kojčin, Ph.D., Cara Nikolaja III Street no. 92, Belgrade, Serbia, Phone: +381 63 83932 16, E-mail: KOJCINZ@gmail.com

EP 2015 (62) 3 (831-848) 


\section{Introduction}

Statistical data on agriculture in the Republic of Serbia are collected, processed and published by the Statistical Office of the Republic of Serbia which, as the only state authorized institution performs tasks under the current Law on Statistics through its regional offices. On the other hand, the Ministry of Agriculture, Forestry and Water Management, according to their needs and requirements in the process of research and the adoption of appropriate regulations and within their competence and their own requirements collects data on agricultural production, handles a large number of registers and records and submits data to the Statistical Office of the Republic of Serbia. Collected and analyzed statistical data are published in the publications of the Statistical Office of the Republic of Serbia.

Office publications are available in printed and electronic form. However, modern tendencies in the development of information technology on one hand and analysts requirements on the other, imposed the need for statistical data to be available to all users, and that is why the access to statistical data has been provided via Internet and they are stored in the projected database. Consequently, at the beginning of 2010, the Statistical Office of the Republic of Serbia Database was formed. The database was formed with about 400 indicators and in the meantime it has been developed and amended with data, so that today it contains data for 735 indicators in all areas of social and economic life from which the Office collects and processes statistical data.

The objectives of the Paper have been to examine data availability in the agriculture area in the Statistical Office of the Republic of Serbia Database and to explore the possibilities of using Database in the agriculture research and analysis. This could not be done without an analysis of the model, structure and organization of the Database, on the one hand, and the analysis of the number and type of data available in the field of agriculture, on the other hand. The basic hypothesis was that it is possible to improve the Database so as to improve existing performance and after analyzing the Database, we proposed the solutions in this regard. Another hypothesis was that the latest achievements in information technology could be applied in the redesigning of the Statistical Office of the Republic of Serbia Database.

The methodology used in the analysis has been presented in the first part of the study. In the second part, The Statistics of Agriculture in the Republic of Serbia, it has been shown what is the coverage of agricultural statistics in the Republic of Serbia. In the third part, entitled Agriculture in the Statistical Office of the Republic of Serbia Database, it is described how the data on agriculture are classified in the database. In the fourth part of the paper, entitled The Possibilities of Using the Database in the Analysis, it has been shown what are the possibilities of using the database regarding the ways of displaying data and generating the desired series and how the choice of qualitative and numerical characteristics, time period and territory observation can provide series of structures and the time series for indicators of agriculture as an output record from the database. In the fifth part of the paper, The Results of the 2012 Agriculture Census in the Database, it is described how the data of the 2012 Agriculture Census are modelled and presented in the database. In the sixth part of the 
paper, Agriculture Development Indicators, we have explored what economic indicators and indicators of agricultural development can be found in the database. The seventh part, Results and Discussion, has briefly pointed to the possibility of redefining the Web application through which otherwise, we access the database to allow the crossing of different indicators at several different conditions and criteria. The existence of multidimensions in databases becomes evident and that is certainly of great benefit to the end-user. In addition, a system to improve the storage and accessing data of the Statistical Office of the Republic of Serbia was proposed. Finally, in Conclusions, the summary has been given and it was pointed to the need to supplement the database with indicators obtained by the methods of calculation and analysis, considering the fact that these indicators are currently available only in the publications of the Statistical Office of the Republic of Serbia.

\section{Methodology}

Databases are physically formed in database management systems (Data Base Management Systems - DBMS). When it comes to the DBMS, database management system used by the Republic Statistical Office is SQL Server ${ }^{5}$, which as any other database management system has its specifics in the domain of usage.

Methodological assumption on the subject matter requires the definition of the so-called entity-relation model (E-R Model) in the database. This model is highly usable and it defines the interaction between the real world and conceptual scheme that is presented in the form of diagram. E-R Model consists of an entity, attribute and relations between entities. Stable and proper database structure means properly designed database thus creating the basis for functional data use by a user. Operation speed, redundancy elimination and data integrity achievement are the features that indicate normalized database which generates quality data structure.

Setting queries over data in a database requires the implementation of procedures relating to the scope of activities involved in getting and retrieving data from a database. Before a query is activated, the system translates the query into a form that is understandable to the database management system. The language used to make a query to obtain data from a database and is user oriented is SQL (Structured Query Language). In addition to setting a query, an important step in obtaining valid data from database is query optimization. There are tools used for query optimization which involve complex strategies including specific indices. In the framework of indices related to the optimization the entire functionality comes down to database tuning. Specifically, in the case of SQL Server there is a tool called Index Tuning Wizard (Chaudhuri et al., 1999) which contributes to better quality and easier access and obtaining data.

Methodological approach to the area in the database domain is specific because it requires a series of logical explanations and captures. The Statistical Office of the Republic of Serbia Database physically represents normalized database formed in

5 SQL is an abbreviation of Structured Query Language, the language used to query in order to obtain data from the database.

EP 2015 (62) 3 (831-848) 
DBMS SQL Server. Designing, modelling and setting of database are not related to an end user. The end user should neither be able to update existing data nor change any data structure. The end user is allowed to access the parts of database through web application. Since the Office has had many areas that are not correlated among themselves, data are classified by areas.

The Paper subject refers to the data in the area of agriculture. Data are offered to interested users and researchers through web application. Through forms that allow data filtering and selecting the offered criteria, there is actually a query made over data which drives SQL code and thus defines the query which then has to present the required data in relation to the set task.

\section{The Statistics of Agriculture in the Republic of Serbia}

The Statistics of agriculture in Serbia is very developed: "Within the area of agricultural statistics compiled are the data on agricultural land areas, categories of land use, sown and planted areas - by species/kinds of crops and plants, production and yields for about 60 cultures, number of livestock - by species and categories, output of animal products (meat, milk, eggs, wool, honey), as well as the data on slaughter of animals - by species. The above mentioned data are compiled through regular surveys (18), in accordance with the prescribed methodology, and also applying the method of accounting and analysis (accounting of agricultural production physical volume, accounting of crop production - livestock increase and meat production, by kinds), in accordance with the Official Statistics Law and the Regulation stipulation the plan of official statistics for the respective year.'(Statistical Office of the Republic of Serbia, 2013). The description of statistical area Agriculture and Fishery, the review of publications and information in the area of agriculture, as well as survey methodology in this area can be found on the website of the Office (www.stat.gov.rs).

The Statistics of agriculture in Serbia include: statistics of crop production, livestock breeding, fishery, calculation of the physical volume index of agricultural production and price statistics. Statistics of crop production collects data on agricultural land, sown areas, harvested areas, yields and production of agricultural products in the Republic of Serbia. Livestock Breeding Statistics includes data on livestock number and livestock products eggs, honey, milk and wool. The data for these statistics are obtained through regular annual surveys, in cooperation with the Ministry of Agriculture, Forestry and Water Management, together with a monthly survey on livestock slaughter and meat production. Fishery Statistics collect data on fish production, area and number of fishing households, assets and number of employees on them, information on the number of professional fishermen and the quantity of fish caught and about restocking. Data from these three areas are available as preliminary data in electronic and printed forms in the edition of the Office "Communications" and in the publication "Monthly Statistical Bulletin", while the final data are published in the regular publications of the Office "Statistical Yearbook of the Republic of Serbia" and "Municipalities in the Republic of Serbia ".

Indices of agricultural production physical volume are obtained from regular surveys in the 
scope of the Statistics of Agriculture on produced quantities of plant and livestock products, as well as data on average prices of agricultural products in the Republic of Serbia. The product list includes all economically important agricultural products. Indices are published in the Statistical Yearbook of Serbia. Besides, they are available in electronic form, on the website of the Office, but only for the year 2011.

Price statistics in agriculture include: Producer price indices of agricultural and fishery products, as well as the price indices of reproductive material, labour tools and services in agriculture. Price indices of agricultural and fishery products are calculated on monthly and annual basis, in accordance with the methodology of the European Union and are published in the "Monthly Statistical Bulletin". In addition to the price indices, average monthly purchase prices of producers of agriculture and fishery products are also published in the Bulletin.

A special group of data in the area of agriculture consists of Agriculture Census data, which was conducted in 2012. The Census data can be found on the website of the Office and on the website www.popispoljoprivrede.stat.rs, and the Office published several specialized publications dealing with the analysis of the Census results.

\section{Agriculture in the Statistical Office of the Republic of Serbia Database}

The indicators in the database of the Statistical Office of the Republic of Serbia are classified into 24 areas. The database can be accessed through the website of the Statistical Office of the Republic of Serbia or directly via the web page (http://webrzs.stat.gov.rs/WebSite/Public/ ReportView.aspx), where access to the database is enabled to every visitor. In addition to the indicators, methodological explanations and the most important definitions are available for each indicator. Indicators in the database can be observed by different qualitative and numerical characteristics. Furthermore, there is a choice of territory, a period of observation and the type of data to be displayed. After the selection of characteristics, time period and data types, a report in the form of a series of data, or two-dimensional tables containing series of structures and time series are generated from the database.

Agriculture indicators in the database can be found within the area of Agriculture and Fishery. This area is divided into three sub-areas: Agriculture Census sub-area which contains data from the 2012 Census of Agriculture, Crop Farming sub-area, within which there are data on crop production and Livestock Breeding sub-area which includes the indicators of livestock production. Sub-areas are further divided into narrower sub-areas where there are individual indicators.

Apart from the area of Agriculture and Fishery, information on agriculture can be found in the following database areas as well: Prices, National Accounts and Employment and Earnings. In the area of Prices, the indicators of producer price indices of agricultural and fishery products (for the period from 1999) and the average annual purchase prices of agricultural products (1994 to present) can be found in the database. In the area of National accounts within the Gross Domestic Product and Gross Value Added indicators, one can find data on the share of all activities, including agriculture, in gross domestic product of Serbia 
on an annual and quarterly basis, data on the gross value added in agriculture at constant and current prices and growth rates of gross value added of agriculture, by years and quarters. Data on employment in agriculture can be found in the area of Employment and Earnings, within the indicator Employed persons aged 15 and over by NACE Rev2 sections ${ }^{6}$. In addition, data on employment in agriculture can be found in the Agriculture Census data.

In order to retrieve the required data, the user is able to select first area, then sub-area and finally the desired indicator. The offered characteristics vary depending on the indicator and can be qualitative - type of production, agriculture area, type of products, and numerical - the value in Euros, the area in hectares and other. The user has the option of selecting the type of data to be displayed (absolute and / or relative indicators, value and / or quantitative data, base and / or chain indices, total yield, yield per unit, area in hectares, number of cattle at the beginning and / or at the end of the year), territories of observation (Republic of Serbia, Vojvodina, Central Serbia and narrower territorial units) as well as the way to display the results (name, code, code and name). After selecting the desired option, the required report is generated from the database and is displayed in a table. After receiving the report it is possible to save data in specific formats in the application, such as .xls, .xml or .pdf, noting that the number of records is limited to 100,000 .

\section{The Possibilities of Using Database in the Analysis}

By choosing different numerical and qualitative characteristics, time period of observation and the territory, it is possible to obtain a large number of structure series and time series for agriculture indicators in the database. Depending on the indicators, the database provides a choice of data to be generated. For example, for the Livestock Balance indicator in the Livestock Breeding sub-area, the following data are available: the number of cattle at the end of the year, the number of cattle at the beginning of the year, breeding, purchase, selling, slaughtering and mortality. For the Crop Farming sub-area (which is at the same time an indicator because this sub-area is not broken down in details by indicators, but the production of any agricultural product in particular is seen as a category of crop production qualitative characteristic), the following data are available: harvested area in hectares, number of fruit trees in thousands, number of grapevines in millions, total yield in tons and yield per unit in kilograms. The criteria for selecting the data will depend on which agricultural crops is observed.

The length of the period in which it is possible to observe individual indicators differs. For some indicators (price index) data are available starting from 1990s, for some from 2001 (the calculation of gross domestic product, gross domestic value added by activities), while for some indicators there are data available even from 1947. For most agricultural products in Crop Farming sub-area data are available from 1947. For example, it may be concluded what was the wheat production in the first years after World War II, where it can be observed that over time harvested area under wheat was divided in more than halves

6 NACE Rev. 2 is the Statistical Classification of Economic Activities in the European Community, Rev. 2 
from 1947 till today (from 1,035,237 ha in 1947 to 480,539 ha 2012), and the total yield almost doubled (from 1,076,370 tons in 1947 to 1,910,914 tons in 2013). Long time series allow comparisons and analysis of trends and dynamics of the observed phenomena over a longer period of time. The production of other crops and how the production changed over time can also be analyzed, as well as factors of influence for a longer period of time within which there is a possibility of some comparisons by age, etc.

Table 1. shows the grain production in Serbia in 1947 and 2012 - harvested area, total yield and yield per unit in kilograms. The table is an output report from the database according to the requested parameters.

Table 1. Production of Grains in the Republic of Serbia in 1947 and 2012

\begin{tabular}{|l|r|r|r|r|r|r|}
\hline & \multicolumn{2}{|c|}{ Harvested Area, ha } & \multicolumn{2}{c|}{ Total Yield, t } & \multicolumn{1}{c|}{ Yield per Unit, kg } \\
\hline REPUBLIC OF SERBIA ${ }^{1}$ \\
\hline Crop farming & $\mathbf{1 9 4 7}$ & $\mathbf{2 0 1 2}$ & $\mathbf{1 9 4 7}$ & $\mathbf{2 0 1 2}$ & $\mathbf{1 9 4 7}$ & $\mathbf{2 0 1 2}$ \\
\hline Wheat & $1,035,237$ & 480,539 & $1,076,370$ & $1,910,914$ & 1,039 & 3,977 \\
\hline Barley & 85,032 & 77,335 & 97,520 & 266,383 & 1,146 & 3,445 \\
\hline Corn & $1,286,243$ & 1268,544 & $2,533,110$ & $3,532,602$ & 1,969 & 2,785 \\
\hline Oats & 127,686 & 29,541 & 109,340 & 66,059 & 856 & 2,236 \\
\hline Rye & 55,737 & 3,934 & 51,900 & 9,567 & 931 & 2,432 \\
\hline \multicolumn{7}{|c|}{ Source: Statistical Office of the Republic of Serbia } \\
\hline \multicolumn{7}{|c|}{${ }^{1}$ From 1999- N/A AP Kosovo and Metohija } \\
\hline
\end{tabular}

Source: Statistical Office of the Republic of Serbia, 2013;

Graph 1. shows trends in the production of grains, for each year in the period 1947-2014.

Graph 1. Production of Grains in the Republic of Serbia 1947-2014

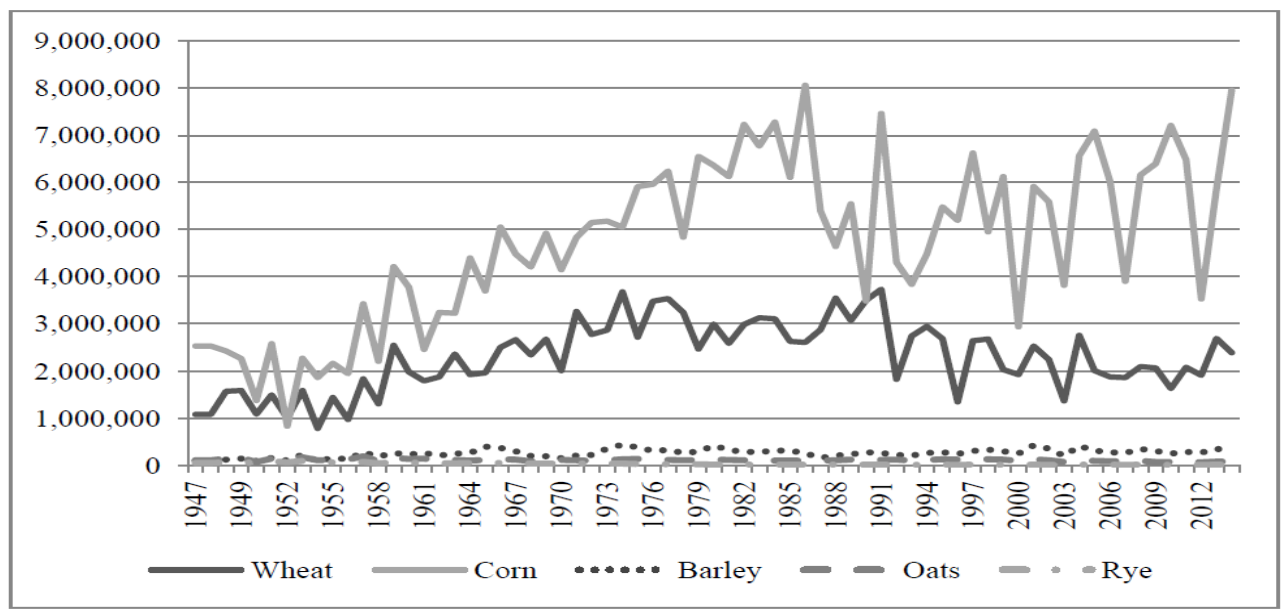

Source: Statistical Office of the Republic of Serbia, 2014; 
Graph 1. clearly shows that grains production is dominated by two cultures, wheat and corn, while the production of other grains is on a much lower level. It may be noted that the production of maize and wheat had a growing trend until early 1990s, and further on it continues to fluctuate with a tendency of fall. The reasons for these fluctuations in the production of two major crops were the following: the disintegration of the Socialist Federal Republic of Yugoslavia caused market loss, subsidized production was abolished, reduction of livestock also affected reduced production of corn and wheat, and there was a collapse of rural cooperatives which also influenced the decrease in production.

Graph 2. shows the trends and dynamics in livestock production based on data for the Livestock Balance indicator in Livestock Breeding sub-area, for the period 1947- 2013 (data for 2013 are the latest available data). It shows the number of heads at the end of the year - cattle, pigs and sheep, without poultry, for which data in the database has existed only since 1997.

Graph 2. Livestock Balance - the number of heads at the end of the year, the Republic of Serbia, 1947 - 2013, in thousands

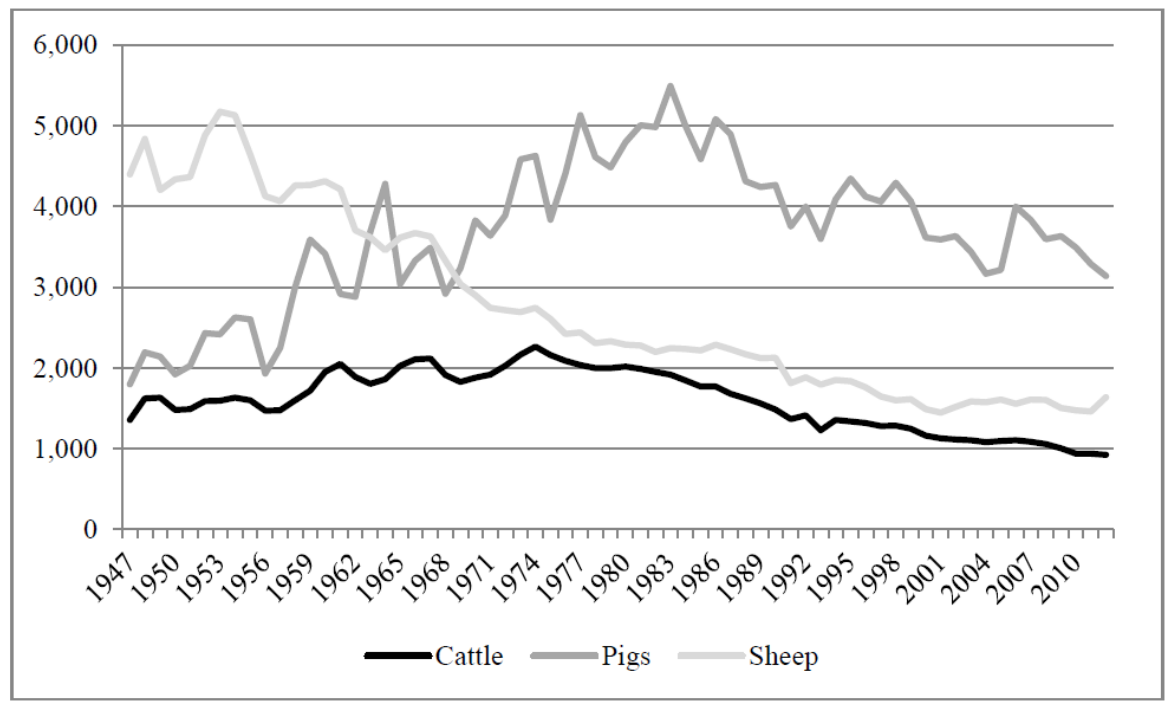

Source: Statistical Office of the Republic of Serbia, 2013;

Based on these data we can see that in the first decades after the World War II the number of heads of cattle and pigs increased, while the number of sheep decreased. Since the Census of Agriculture in 1960, as explained in (Popović, 2014), there have been three different periods. In the first period, until mid-1980s, production increased, primarily due to an increase in the number of pigs. Since the mid-1980s the reduction of the number of cattle has been expressive both due to a decrease in the number of pigs and heads of cattle. The total number of cattle heads in Serbia continued to fall until the mid-1990s. Since the second half of the 1990s, this negative trend of decline in the total number of cattle heads has continued concluding that a substantial impact on the reduction was caused by a decline in the number of cattle. 
As it is possible to view the indicators in the database simultaneously according to several different qualitative and numerical characteristics, there is a large potential for analysing the observed phenomena. For example, consider farms (agricultural holdings) structure by their economic size and by particular type of agricultural production. Farms by economic size is an indicator within the Census 2012 sub-area, narrower sub-area Land $^{7}$. Farms by economic size indicator is possible to view simultaneously according to farm economic size (numerical characteristic), type of crops that are grown (qualitative characteristic) and legal status (also qualitative characteristic). Agricultural holdings by economic size in the database are classified into 14 classes ranging in the interval from 0-2,000 Euros up to 3,000,000 Euros and more. As for crops that are grown, farms can be seen according to the production of certain types of grains, or the production of some other products (legumes, industrial crops, fruits and vegetables). Categories of farms legal status characteristic are: family farms, legal entity or entrepreneur. Regarding the type of data, it is possible to obtain the number of farms and farm area in hectares for this indicator. It is also possible to get detailed information by regions and cities in Serbia.

Based on the results of the 2012 Census, the average value of family farms in the Republic of Serbia amounts to 4,990 Euros, while the average economic size of farms for legal entities and entrepreneurs amounts to 204,775 Euros (Cvijanović et al., 2014). Here we shall consider farms by economic size dealing exclusively with the production of grains and the structure of these farms according to their legal status. After selecting the characteristics and data types, one can get the required data which are presented in Table 2.

Table 2. Number of Farms under Grains by Economic Size of Farms, Republic of Serbia, 2012

\begin{tabular}{|c|c|c|c|c|}
\hline & Total & Family Farms & Legal Entity & Entrepreneur \\
\hline \multicolumn{5}{|c|}{ Number of farms by economic size } \\
\hline \multicolumn{5}{|c|}{ REPUBLIC OF SERBIA $^{1}$} \\
\hline TOTAL & 458,196 & 457,193 & 940 & 63 \\
\hline $0-2,000$ & 158,576 & 158,447 & 119 & 10 \\
\hline $2,000-4,000$ & 113,959 & 113,894 & 59 & 6 \\
\hline $4,000-8,000$ & 102,096 & 102,022 & 65 & 9 \\
\hline $8,000-15,000$ & 49,775 & 49,682 & 82 & 11 \\
\hline $15,000-25,000$ & 17,258 & 17,200 & 55 & 3 \\
\hline $25,000-50,000$ & 10,491 & 10,403 & 84 & 4 \\
\hline $50,000-100,000$ & 4,484 & 4,382 & 91 & 11 \\
\hline $100,000-250,000$ & 1,126 & 1,010 & 112 & 4 \\
\hline $250,000-500,000$ & 218 & 138 & 77 & 3 \\
\hline
\end{tabular}

7 Economic size of agricultural holdings is an average gross value of agricultural production at manufacturer price and is expressed in Euros.

EP 2015 (62) 3 (831-848) 


\begin{tabular}{|c|c|c|c|c|}
\hline & Total & Family Farms & Legal Entity & Entrepreneur \\
\hline \multicolumn{5}{|c|}{ Number of farms by economic size } \\
\hline \multicolumn{5}{|c|}{ REPUBLIC OF SERBIA ${ }^{1}$} \\
\hline $500,000-750,000$ & 51 & 11 & 39 & 1 \\
\hline $750,000-1,000,000$ & 32 & 2 & 30 & 0 \\
\hline $1,000,000-1,500,000$ & 49 & 1 & 47 & 1 \\
\hline $1,500,000-3,000,000$ & 41 & 1 & 40 & 0 \\
\hline $3,000,000-$ & 40 & 0 & 40 & 0 \\
\hline
\end{tabular}

Source: Statistical Office of the Republic of Serbia, 2010;

In addition to the Farms by economic size indicators, there are the following indicators for farms in the database: Farms by type of farming, Farms by agricultural size of farm, Farms with different crops by agricultural size of farm, Irrigation farms. Provided that it is possible to cross all existing numerical and qualitative characteristics for indicators, there are many possibilities for the analysis of agricultural holdings in the Republic of Serbia, their economic size as well as the number and area of farms under different agricultural products.

\section{The Results of the 2012 Agriculture Census in the Database}

The 2012 Agriculture Census was conducted in the period October 1 to December 15, 2012, in accordance with the Law on 2012 Census of Agriculture ${ }^{8}$. The Census was conducted by the Statistical Office of the Republic of Serbia and it was financially supported by the European Union which took part in the costs of the Census. The main objectives of the Census were to get a comprehensive review of the national agriculture structure, compiling internationally comparable data base on agriculture, providing statistical data on agriculture for the purpose of formulating policies for agricultural development and the formation of the Statistical Register of agricultural holdings, the general improvement of agricultural statistics in Serbia, ensuring international comparability of data and harmonization with EU standards. From the perspective of users and data providers, "Data collected by the Census of Agriculture will contribute to the acquisition of knowledge about the real situation in the agriculture of the Republic of Serbia. It is of great importance for all future users of aggregated data, particularly for data providers - the list of units who will be able to plan agricultural production better, to apply for national and European funds to support agriculture and gain knowledge about which agricultural branch should be invested in." (Statistical Office of the Republic of Serbia, 2013).

The Census of Agriculture surveyed 937,210 households and 4,200 legal entities and

8 Before The 20102 Agriculture Census, the last comprehensive agricultural census for the territory of the Republic of Serbia was conducted in 1960. 
entrepreneurs. The most important results of the 2012 Agricultural Census are shown in the Table 3 .

Table 3. Basic Indicators of Agriculture in the Republic of Serbia, in 2012

\begin{tabular}{|l|r|}
\hline Basic Indicators, Republic of Serbia, 2012 & 631,552 \\
\hline Number of agricultural households & $3,861,477$ \\
\hline Agricultural land area, ha & 908,102 \\
\hline Number of cattles & $3,407,318$ \\
\hline Number of pigs & $1,736,440$ \\
\hline Number of sheep & 231,837 \\
\hline Number of goats & $26,711,220$ \\
\hline Number of poultry & 665,022 \\
\hline Number of beehives & 410,894 \\
\hline Number of own double-axle tractors & $1,442,628$ \\
\hline $\begin{array}{l}\text { Number of households members and full-time employees on farms, } \\
\text { who are engaged in agricultural activity }\end{array}$ & \\
\hline
\end{tabular}

Source: Statistical Office of the Republic of Serbia, 2010;

Data from the Census of Agriculture are available in the database of the Statistical Office of the Republic of Serbia in the area of Agriculture and Fishery, sub-area Agriculture Census, narrower sub-area 2012 Census. Within 2012 Census sub-area, 2012 Census data are classified into the following narrower sub-areas: Land, Livestock and Bees, Labour Force and Other Activities, Farm Management and Production Method in Agriculture. The Land sub-area provides information on the farms and agricultural land. Livestock and Bees sub-area is divided into several narrower sub-areas: Cattle, Cows, Pigs, Sheep, Goats, Poultry within which there are detailed data on livestock fund and farms where cattle is grown. The Labour Force and Other Activities subarea provides information on the labour force in agriculture, the labour force by gender and type of production as well as data on the type of production in agriculture and specialization in the production of certain agricultural products. In the Farm Management sub-area one can find data on the ways of managing farms, managers training, agricultural equipment, the type of tenure in agriculture. In the Production Method in Agriculture sub-area there is a large number of narrower sub-areas: Type of Processing, Soil Conservation, Animal Grazing, Animal Housing, Manure Storage and Treatment Facilities and Manure Application, and within which there is a large number of indicators.

\section{Agriculture Development Indicators}

In addition to data on agricultural production, economic indicators and indicators of achieved agricultural development are of great significance for the analysts. According to "Agriculture", the Bulletin of the Statistical Office of the Republic of Serbia", the most important economic indicators in agriculture are the share of agriculture in

9 The bulletin "Agriculture" was published until 2010, but is no longer published.

EP 2015 (62) 3 (831-848) 
$G D P$ and the share of agriculture in export and import, and indicators of agricultural development are physical volume index of agricultural production, the number of companies, agricultural cooperatives and farms, purchase of agricultural products and the number of employees in agricultural activities (Statistical Office of the Republic of Serbia, 2010). Nowadays, some of these indicators are available in the database, while others can only be found in the publications of the Office.

For example, data on gross value added of agriculture (gross value added, gross domestic product share and growth rates) can be found in the database within the area of National Accounts within the indicator Gross Domestic Product and Gross Value Added by Activities. Export and import can be found in the Office publication Monthly Statistical Bulletin, for agriculture, forestry and fishery, in millions of $\$$ as well as the corresponding indices. In the database, however, in the area of External Trade, there are no data on export and import of agricultural products, but the export and import of products are shown according to Standard International Trade Classification - SITC. It is a hierarchical, economic classification of products according to the level of production, and not by economy sectors. Information on the sale and purchase of agricultural products of agriculture, forestry and fishing can also be found in the publication Monthly Statistical Bulletin but not in the database in the area of Domestic Trade, as might perhaps be expected.

Data on employment in agriculture can be found in the database, both in the Census of Agriculture, and within the area of Employment and Earnings (Employed persons by sector). In addition to these indicators, according to (Simović et al., 2012), share of the agricultural population in the total population and the share of active agricultural population in the agricultural population are also important for analysis. The share of agricultural population in the total population is covered by the Census of Population, Households and Dwellings, which was conducted in Serbia in 2012, and the data have been published in special publications - Census Atlas (Statistical Office of the Republic of Serbia, 2014).

The database does not include the indices of physical volume of production in agriculture, probably the most important indicator of production, which is now only found in the Statistical Yearbook of the Statistical Office of the Republic of Serbia. Thus, significant economic indicators of agriculture - agricultural production indices, the share of agriculture in import and export and data on purchase and sale of agricultural products are not available in the database. Mainly, these are data obtained by calculation methods and analysis. In addition to these indicators, the database would be significantly enriched by some economic indicators of agriculture that Statistical Office of the Republic of Serbia does not calculate and publish for now. These are financial indicators such as data on the agricultural budget share in the budget of the Republic of Serbia and various financial indicators which are currently only a subject of individual author calculations and a result of individual research efforts. Furthermore, these financial indicators are presented by some state institutions dealing with the analysis in this area. For example, the share of the agricultural budget in the national budget is 
given in (Veselinović, Drobnjaković, 2014) and in (Radović, 2009), while the financial indicators of companies in the agricultural sector are analyzed in (National Agency for Regional Development, 2012). Data on investment in agriculture till the beginning of the global economic crisis can be found in (Pejanović, Milić, 2008), where data source was the Bulletin of the Statistical Office of the Republic of Serbia "Investments of the Republic of Serbia"10, while the direct foreign investment data can be found in (Kapor, 2009), where data sources were the National Bank data on direct foreign investment and UNCTAD (United Nation Conference on Trade and Development). When Serbian authors deal with investment in agriculture, they refer to the budget data, for example in (Miletić et al., 2012), while commercial banks data on the amounts of subsidized shortterm and long-term loans to agriculture have not been consolidated in the literature. In fact, those data on investment in agriculture and its availability in the database would be of great importance for the analysis of the situation and tendencies in the development of Serbian agriculture.

\section{Results and Discussion: How to Improve the Availability of Data in the Field of Agriculture}

In the previous parts of the Paper we described the technical characteristics of the Database and explained the options of accessing, filtering and downloading data from the Database. The indicators of agriculture that are available in the Database were listed and the possibilities of using Database were analyzed. Subsequently, the question was raised whether these possibilities could be improved. It was hypothesized that it was possible to improve the database by improving the existing performances. Another hypothesis was that the latest developments in information technology could be applied in re-designing the Database. One improvement has been proposed in the previous part of the Paper: it is necessary to enrich the Database with data which can only be found in the Office printed publications, as well as data obtained by calculation methods and analysis, such as the indicators of the agricultural development and various financial indicators. Another advancement option refers to technical improvements that is, to the improvement of the methods of data storage and access to the Database through re-designing Database.

Recently, the rapid advancement of information and communication technologies, as well as the growing number of demands of researchers involved in new issues and analyses have raised the problem of access to necessary information. Certainly one should not expect the ability to access all data in the database, but it is possible to improve getting the required outputs. This refers to the possibility of querying of the database where filtering data will be allowed by using one or more of the conditions and aggregate functions, which together would provide a display in multiple dimensions. When it comes to the queries of the database, it is understood that users through webenabled applications should be provided such controls, which will provide input

10 The Bulletin is no longer published but data on agricultural investment can be found in the Office press releases "Investment of the Republic of Serbia" which are published annually. 
requirements and criteria in the simplest possible way. The conditions and criteria that are entered this way, as well as possible options for using aggregate functions should then be generated in the SQL code that is passed to the database and will return a response, namely the output results to the user, as defined in (Silberschatz et al., 2011). Multi-dimensionality in the database should primarily provide direct support to analysts in setting up various queries, in order to obtain results, as shown in (Riordan, 2006).

The first step towards improving the storage system and accessing data would be the definition of existing opportunities in the sphere of information technologies. Given the fact that the access to the data of the Statistical Office of the Republic of Serbia Database is provided via Internet, meaning web application, it is necessary to think about improvement in the direction of using modern trends in the area of information technologies based on the web.

Web based applications are basically very demanding systems. Data management is one of the more complex tasks of these systems as it is typically done with quite a number of data. The challenge of managing data in databases varies in different scientific disciplines. While in some disciplines management problem relates to the organization of data on a large scale, in other scientific disciplines problems arise from the growing complexity of data and asking questions about them. Each of the challenges (large volume of data, rapidly changing environment, need for a better model structure and the use of complex queries) significantly complicates database design. These are the problems that make database administrators work with data in an explorative manner so that the defined query depends on the preceding one thus linking queries together and the answers provided by queries are immediately available. This means that data processing is rarely accessed offline as well as the analysis of "Big Data" approach (Heinis et al., 2011).

Recently, so-called Cloud systems for storing a large amount of data have been increasingly used and developed. The term "Big Data", a relatively new concept, refers to data whose setting is extensive and so complex that traditional data processing is no longer adequate and sufficient. Among the challenges of "Big Data" returns, inter alia, are analysis, data collection, sharing, visualization, but primarily data storage. It is because of the problem of a large number of data storage and a large number of users accessing data via web that Cloud founded databases operating on the Cloud computing platform should be emphasized.

In relation to the above, it is possible that a large number of data stored by the Republic Statistical Office and keep increasing, will be stored in the Cloud SQL Server database management system. Cloud SQL Server supports SQLAzure-relational database service. Cloud SQL Server supports the use of database partitions as well as its replications. Transactions made over database are always limited to a single partition unless the reading of SQL query is not done on a separate isolation level (Agrawal et al., 2015).

Another specific use of "Big Data" refers to a new multidisciplinary scientific field - Visual Analytics which defines visualization, interactive data analysis and data management (Fekete, Silva, 2012). 
In general, statistical database is a collection of data using queries which take general characteristics of some data sub-groups allowing for responses to information details about data. Queries of these databases almost always use aggregate functions and they are called statisticalsumqueries (Jonsson, Krokhin, 2008). Working with these databases almost always carries certain specifics because sometimes it is necessary to protect the presentation of certain types of data or present data only for some cases. This sort of statistical queries brings about the problem of data access security. Many examples of such databases include database perturbation (Liew et al., 1985), as well as statistical queries for getting answers, but also the limitation of the queries themselves.

Statistical databases whose access is possible via Internet and which have a similar or the same data review as the Statistical Office of the Republic of Serbia can be viewed via website: https://data.un.org/. According to the given sites it is possible to compare data availability to the Office data availability and it is also possible to notice how many sites there are that are provided by advanced search and data calculation from the selected country database. However, the analysis of such data availability in the world would be the topic of another paper.

\section{Conclusion}

The Statistical Office of the Republic of Serbia Database is certainly a very rich with data, and when it comes to agriculture, it is also rich with the 2012 Census data. A special emphasis in this Paper is given to data in the area of agriculture that can be obtained through the web application as a way to access the Database. We have displayed the areas and sub-areas of agriculture offered by this application, listed the available agricultural indicators and showed the possibilities of using Database. Basically, the objective of the Paper was to point to the great benefit of the existence of this kind of access to data stored in the Database, but also to the possible methodological and technical improvements of application via which we access the database.

The proposed methodological and technical improvements refer to the re-design of Database based on the modern cloud founded databases that exist in the world nowadays. We suggested the transformation of database towards Cloud SQL Server database management system. In addition, the application of achievements offered by Visual Analytics would improve visualization, interactive data analysis and data management.

In addition to these technical improvements, when it comes to information in the field of agriculture, it was proposed to enrich the Database with data that are currently available only in the Office printed publications. Attention has also been paid to the fact that through the application that access the database one cannot obtain calculated indicators, i.e., data obtained by the methods of calculation and analysis. Also, the indicators of agricultural development and various financial indicators are not available in the Database. Although some of these indicators can be calculated or they exist in written publications of the Office, the possibility of obtaining time series of these indicators from the databases would be of great importance and benefit to analysts. 


\section{Literature}

1. Agrawal D., Abbadi A., Salem K. (2015): A Taxonomy of Partitioned Replicated Cloud-based Database Systems, Data Engineering Bulletin, vol. 38, no. 1, pp. 4-10, IEEE Computer Society, Washington, D.C., (available at: http://sites.computer.org/ debull/A15mar/A15MAR-CD.pdf).

2. Chaudhuri S., Christensen E., Graefe G., Narasayya V., Zwilling M. (1999): SelfTuning Technology in Microsoft SQL Server, Data Engineering Bulletin, vol. 22, no. 2, pp. 20-27, IEEE Computer Society, Washington, D.C., (available at: http://sites. computer.org/debull/99june/issue1.htm).

3. Cvijanović, D., Subić, J., Paraušić, V. (2014): Poljoprivredna gazdinstva prema ekonomskoj veličini $i$ tipu proizvodnje $u$ Republici Srbiji, Republički zavod za statistiku, Beograd, Srbija, (available at: http://pod2.stat.gov.rs/ ObjavljenePublikacije/Popis2012/TIPOLOGIJA.pdf).

4. Fekete J.D., Silva C. (2012): Managing Data for Visual Analytics: Opportunities and Challenges, Data Engineering Bulletin, vol. 35, no. 3, pp. 27-37, IEEE Computer Society, Washington, D.C., (alvailable at: http://sites.computer.org/debull/A12sept/ issue 1.htm).

5. Heinis T., Branco M., Alagiannis I., Borovica R., Tauheed F., Ailamaki A. (2011): Challenges and Opportunities in Self-Managing Scientific Databases, Data Engineering Bulletin, vol. 34, no. 4, pp. 44-53, IEEE Computer Society, Washington, D.C., (available at: http://sites.computer.org/debull/A11dec/issue1.htm).

6. Jonsson P., Krokhin A. (2008): Computational complexity of auditing finite attributes in statistical databases, Journal of Computer and System Sciences, vol. 74, Issue 5, pp. 898-909, Academic Press, San Diego, CA, (available at: http://www. sciencedirect.com/science/journal/00220000/74/5).

7. Kapor, P. (2009): Strane direktne investicije u poljoprivredi, Ekonomika poljoprivrede, br. 2/2009, Institut za ekonomiku poljoprivrede, str. 231-24, Beograd, Srbija, (available at: http://bsaae.bg.ac.rs/images/Ekonomika\%20kompletna/2009/ Broj\%202-2009.pdf).

8. Liew C.K., Choi U.J., Liew C.J. (1985): A data distortion by probability distribution, ACM Transactions Database Systems, vol. 10, Issue 3, pp. 395-41. Association for Computing Machinery, New York, (available at: http://dl.acm.org/citation.cfm?id= 3979\&CFID=680258218\&CFTOKEN=26983881).

9. Miletić, V., Milosavljević D., Kostić, B. (2012): Institutional Investment Policy Frameworks for the Agriculture of The Republic of Serbia, Economics of Agriculture, Institute of Agricultural Economics, 3/2012, pp. 363-372, Belgrade, Serbia, (available at: http://bsaae.bg.ac.rs/images/Ekonomika\%20kompletna/2012/ Ekonomika\%20\%20poljoprivrede\%20-\%202012-3.pdf).

10. National Agency for Regional Development (2012): Uticaj finansijske krize na poslovne performanse preduzeća po privrednim granama - komparativna analiza 
Srbije, Hrvatske $i$ Slovenije, Beograd (http://narr.gov.rs/index.php/content/ download/1604/8664/file/Uticaj\%20finansijske\%20krize,\%20web.pdf)

11.Pejanović, R., Milić, D. (2008): Investicije u poljoprivredu Republike Srbije, Ekonomika poljoprivrede, br. 1/2008, Institut za ekonomiku poljoprivrede, str. 9-19, Beograd, Srbija, (available at: http://bsaae.bg.ac.rs/images/Ekonomika\%20 kompletna/2008/Broj\%201-2008.pdf).

12.Popović, R. (2014): Stočarstvo u Republici Srbiji, Republički zavod za statistiku, Beograd, Srbija, (available at: http://pod2.stat.gov.rs/ObjavljenePublikacije/ Popis2012/STOCARSTVO.pdf).

13.Radović, G. (2009): Podrška države u funkciji finansiranja poljoprivrede, Agroekonomika, Poljoprivredni fakultet, Univerzitet u Novom Sadu, br. 41- 42, str. 69-79, Novi Sad, Srbija, (available at: http://agroekonomika.rs/images/arhiva/ agroekonomika 41-42.pdf).

14.Riordan, M.R. (2006): Projektovanje baza podataka, Mikro knjiga, Beograd, Srbija.

15.Silberschatz, A., Korth H., Sudarshan S. (2011): Database System Concepts, McGraw-Hill, New York.

16.Simović, Z., Jeločnik, M., Vasić, Z. (2012): Economic Position Of Serbian Agriculture In The Transition Period, Economics of Agriculture, Institute of Agricultural Economics, 3/2012, pp. 536-546, Belgrade, Serbia, (available at: http://bsaae.bg.ac.rs/images/Ekonomika\%20kompletna/2012/Ekonomika\%20\%20 poljoprivrede \%20-\%202012-3.pdf).

17. Statistical Office of the Republic of Serbia (2010): Agriculture 2009, Belgrade, Serbia, (available at: http://webrzs.stat.gov.rs/WebSite/repository/documents/00/00/05/28/ PoljBilten2009.pdf).

18. Statistical Office of the Republic of Serbia (2013): Agricultural Statistics Development Strategy for the Republic of Serbia 2013 - 2018, Belgrade, Serbia, (availabla at: http://webrzs.stat.gov.rs/WebSite/userFiles/file/O\%20nama/ Dokumenti/Agricultural\%20statistics\%20development\%20strategy.pdf).

19. Statistical Office of the Republic of Serbia (2014): Popisni atlas 2011 Census Atlas, Belgrade, Serbia, (available at: http://pod2.stat.gov.rs/ObjavljenePublikacije/ Popis2011/Popisni\%20atlas\%202011.pdf).

20.Veselinović, B., Drobnjaković, M. (2014): Qualitative and Quantitative Analysis of Micro and Macro Aspects of Agricultural Finance, Economics of Agriculture, Institute of Agricultural Economics, 3/2014, pp. 771-788, Belgrade, Serbia, (available at: http://bsaae.bg.ac.rs/images/Ekonomika\%20kompletna/2014/EP\%20 -\%203\%20-\%202014\%20-\%20kompletna\%20sveska.pdf).

21.Law on 2012 Census of Agriculture, Official Gazette of RS, Srbia, no. 104/09 and 24/11, 2011. 


\title{
SERIJE POLJOPRIVEDE U BAZI PODATAKA REPUBLIČKOG ZAVODA ZA STATISTIKU SRBIJE ${ }^{11}$
}

\author{
Jelena Radović - Stojanovićc ${ }^{12}$, Aleksandra Zečević ${ }^{13}$, Zorica Kojčin ${ }^{14}$
}

\begin{abstract}
Rezime
Ciljevi ovog rada bili su da se istraži koji se podaci o poljoprivredi mogu pronaći u Bazi podataka Republičkog zavoda za statistiku Srbije i kakve su mogućnosti za primenu Baze podataka u istraživanju i analizi poljoprivrede. Baza podataka Republičkog zavoda za statistiku fizički predstavlja normalizovanu bazu podataka formiranu u DBMS SQL Serveru. Metodološki pristup temi rada odnosi se na modeliranje i način korišćenja Baze podataka. Objašnjene su opcije pristupanju, filtriranju i preuzimanju podataka iz Baze podataka. Opisane su tehničke karakteristike Baze, nabrojani su indikatori poljoprivrede, analizirane su mogućnosti korišćenja Baze podataka. Ispitano je da li ove mogućnosti mogu da se unaprede kroz poboljšanje načina skladištenja i pristupa podacima. Zaključeno je da su poboljšanja moguća, i to obogaćivanjem Baze podataka podacima iz oblasti poljoprivrede koji su za sada raspoloživi samo $u$ štampanim publikacijama Zavoda, a zatim, kroz metodološka i tehnička poboljšanja, redizajniranjem Baze podataka po ugledu na cloud zasnovane baze podataka. Takođe, primena dostignuća novog multidisciplinarnog naučnog polja - Vizuelne analitike poboljšala bi vizuelizaciju, interaktivnu analizu podataka i upravljanje podacima.
\end{abstract}

Ključne reči: baza podataka, indikatori poljoprivrede, serije strukture, vremenske serije, Srbija

11 Rad je deo istraživanja u okviru projekta III 41030 - Biološki mehanizmi, nutritivni unos i status polinezasićenih masnih kiselina i folata: Unapređenje ishrane u Srbiji, koji finansira Ministarstvo obrazovanja, nauke i tehnološkog razvoja Republike Srbije. Period trajanja projekta: 2011-2015.

12 Doc. dr Jelena V. Radović - Stojanović, Kriminalističko - policijska akademija, Cara Dušana 196, 11080 Beograd, Srbija, Telefon: +381 64 8922652, E-mail: jelena.rs@kpa.edu.rs

13 Doc. dr Aleksandra T. Zečević, Univerzitet u Beogradu, Ekonomski fakultet, Kamenička 6, 11000 Beograd, Srbija, Telefon: +381 69 4496621, E-mail: azecevic@ekof.bg.ac.rs

14 Dr Zorica D. Kojčin, Cara Nikolaja II, br. 92, Beograd, Srbija, Telefon: +381 638393216 , E-mail: $\underline{\text { KOJCINZ@gmail.com }}$ 